\title{
UPAYA MENINGKATKAN HASIL BELAJAR IPA DENGAN MENERAPKAN MODEL PEMBELAJARAN GUIDED DISCOVERY
}

\author{
Oleh: Diplan., M.Pd* dan Sari Mulia**
}

\begin{abstract}
ABSTRAK
Penelitian ini bertujuan untuk : (1) mendeskripsikan aktivitas belajar IPA peserta didik dengan menerapkan model pembelajaran Guided Discovery, dan (2) mendeskripsikan peningkatan hasil belajar IPA peserta didik setelah menerapkan model pembelajaran Guided Discovery. Jenis penelitian ini adalah penelitian tindakan kelas (PTK) dengan subjek penelitiannya yaitu peserta didik kelas V SDN 7 Selat Hulu Kuala Kapuas. Analisis data menggunakan analisis data kualitatif dan kuantitatif. Hasil penelitian menunjukkan bahwa: (1) model pembelajaran Guided Discovery dapat meningkatkan aktivitas belajar IPA peserta didik, dan (2) peningkatan hasil belajar IPA dengan model pembelajaran Guided Discovery ditunjukkan dengan perolehan nilai rata-rata 67,70 pada siklus I meningkat menjadi 87,08 pada siklus II. Ketuntasan belajar secara klasikal juga mengalami peningkatan dengan nilai $79,2 \%$ pada siklus I meningkat menjadi $100 \%$ pada siklus II
\end{abstract}

Kata Kunci: model pembelajaran Guided Discovery dan hasil belajar IPA

\section{PENDAHULUAN}

Hakekatnya kegiatan belajar mengajar adalah suatu proses interaksi atau hubungan timbal balik antara guru dan peserta didik dalam satuan pembelajaran, sedangkan belajar Slameto, (2006) adalah proses usaha yang dilakukan seseorang untuk memperoleh suatu perubahan tingkah laku yang baru secara keseluruhan, sebagai hasil pengalamannya sendiri dalam interaksi dalam lingkungan.

Guru sebagai salah satu komponen dalam proses belajar menganjar merupakan pemegang peran yang sangat penting. Guru bukan hanya sekedar penyampai materi saja, tetapi lebih dari itu guru dapat dikatakan sebagai sentral pembelajaran. Saat proses pembelajaran guru mengarahkan bagaimana proses pembelajaran itu dilaksanakan.

Karena itu guru harus dapat membuat suatu pengajaran menjadi lebeh efektif juga menarik sehingga bahan pelajaran yang disampaikan akan membuat peserta didik merasa senang dan merasa perlu untuk mempelajari bahan pelajaran tersebut.

Untuk itu diperlukan suatu upaya dalam rangka meningkatkan mutu pendidikan dan pengajaran salah satunya adalah dengan memilih strategi dalam menyampaikan materi pelajaran agar diperoleh peningkatan 
prestasi belajar peserta didik khususnya pelajaran IPA. Carin dan Sund (Wisudawati, 2013). mendefinisikan IPA sebagai "pengetahuan yang sistematis dan tersusun secara teratur, berlaku umum (universal), dan berupa kumpulan data hasil observasi dan eksperemen.

Berdasarkan observasi awal yang peneliti lakukan di SDN 7 Selat Hulu, diketahui bahwa hasil belajar peserta didik pada mata pelajaran IPA semester II (Dua) tahun pelajaran 2014/2015 banyak yang mengalami ketidaktuntasan. Dari 24 orang peserta didik, ada $13(54,2)$ orang peserta didik memperoleh nilai kurang dari 65 atau dibawah kriteria ketuntasan minimal (KKM). Sedangkan yang tuntas yaitu hanya 11 (45,8\%) orang peserta didik. Sedangkan nilai KKM untuk mata Pelajaran IPA adalah 65.

Permasalahan tersebut menyebabkan hasil belajar IPA peserta didik bermasalah. Hamalik (2007:30) hasil belajar tercipta bila seseorang telajar belajar akan terjadi perubahan tingkah laku pada orang tersebut, misalnya dari tidak tahu menjadi tahu, dari tidak mengerti menjadi mengerti.

Nana Sudjana (Sanjaya : 2011), hasil belajar yang dicapai peserta didik dipengaruhi oleh dua faktor yakni faktor dari dalam diri dan faktor dari luar diri peserta didik. Upaya yang dilakukan untuk mengatasi permasalahan rendahnya hasil belajar peserta didik ini, maka perlu suatu usaha untuk meningkatan hasil belajar peserta didik, yaitu dengan melakukan pembenahan terhadap metode penyampaian materi ajar, dan salah satu upaya yang dimaksud ialah melaksanakan pembelajaran dengan menggunakan media pembelajaran yang sesuai di setiap penyampaian materi IPA.

Salah satu media pembelajaran yang sesuai pada mata pelajaran IPA materi pokok sifat-sifat cahaya adalah model pembelajaran Guided Discovery, karena dengan model pembelajaran ini dapat mengatasi verbalisme, menarik perhatian dan minat peserta didik dalam belajar.

Berangkat dari fenomena yang telah diuraikan sebelumnya, peneliti bependapat bahwa dalam setiap menyampaikan pembelajaran IPA materi pokok Sifat-sifat cahaya dengan menggunakan model pembelajaran Guided Discovery akan meningkatkan hasil belajar IPA peserta didik. Maka, Penelitian ini mengangkat judul: meningkatkan hasil belajar IPA dengan menerapkan model pembelajaran guided discovery. Penelitian akan dilakukan di kelas V SDN 7 Selat Hulu Kuala Kapuas tahun pelajaran 2014/2015”.

Tujuan yang ingin dicapai dalam penelitian ini adalah: untuk mendeskripsikan aktifitas belajar pada pembelajaran IPA melalui model pembelajaran Guided Discovery pada peserta didik keles V SDN 7 Selat Hulu dan untuk 
mengetahui hasil belajar IPA dengan menggunakan model pembelajaran Guided Discovery khususnya mengenai sifat-sifat cahaya pada peserta didik kelas V SDN 7 Selat Hulu.

\section{METODE PENELITIAN}

Penelitian ini menggunakan Penelitian Tindakan Kelas (PTK). Menurut Kemmis dan Mc Taggart (1998), penelitian tindakan kelas dilakukan melalui proses yang dinamis dan komplementari yang terdiri dari empat "momentum" esensial, yaitu Penyusunan rencana, tindakan, observasi, refleksi. Subjek penelitian yang peneliti ambil adalah peserta didik kelas V SD Negeri 7 Selat Hulu Kapuas yang berjumlah 24 orang.

Teknik pengumpulan data dilakukan dengan dua cara yaitu dengan observasi dan dengan tes. Teknik analisis data yang digunkan adalah dengan cara kualitatif dan kuantitatif.

\section{HASIL DAN PEMBAHASAN}

Aktivitas guru pada siklus I oleh 2 pengamat memperoleh nilai rata-rata 2,9 dengan pesentase $26 \%$. Sedangkan pada siklus II ada peningkatan menjadi lebih baik, dengan penilaian rata-rata oleh 2 pengamat sebesar 3,4 dengan persentase $30 \%$. Aktivitas peserta didik pada siklus I oleh 2 pengamat memperoleh nilai rata-rata 2,7 dengan pesentase klasikal $27 \%$.
Sedangkan pada siklus II ada peningkatan menjadi lebih baik, dengan penilaian rata-rata oleh 2 pengamat sebesar 3,5 dengan persentase $35 \%$.

Hasil belajar IPA yang diperoleh berdasarkan dari hasil tes akhir (post test) pada peserta didik kelas V di SDN 7 Selat Hulu Kuala Kapuas materi pokok sifat-sifat cahaya dengan menerapkan model pembelajaran Guided Discovery, memberikan hasil pada tes awal nilai rata- rata peserta didik hanya memperoleh nilai rata-rata 61,45 . Nilai ini masih jauh dari kriteria ketuntasan minimal yang ditentukan yaitu 65,00 .

Hasil ketuntasan belajar secara klasikal juga hanya memperoleh nilai sebesar 45,8\%, sedangkan kriteria ketuntasan klasikalnya minimal $85 \%$. Kemudian pada siklus I nilai ratarata peserta didik mengalami peningkatan sebesar 67,70 meskipun masih belum mencapai kriteria ketuntasan minimal, secara klasikal pun hanya masih belum mencapai $85 \%$, karena nilai yang diperoleh pada siklus I hanya sebesar 79,2\%.

Pada siklus II nilai rata-rata peserta didik mengalami peningkatan cukup bagus dengan perolehan nilai rata-rata 87,08 dengan kriteria ketuntasan secara klasikal mencapai 100\%. Peneliti menganggap pada siklus II ini sudah berhasil karena telah mencapai nilai ketuntasan secara kalsikal. 
Namun pada hasil belajar peserta didik terdapat 2 peserta didik yang tidak tuntas sejak tes awal hingga tes siklus II, hal ini menjadi kekurangan dalam penelitian ini. Maka kesepakatan untuk mengatasi masalah tersebut kedepannya adalah memberi pelajaran secara individu dan juga mengadakan remedial kepada 2 peserta didik tersebut.

Jadi, ada peningkatan hasil belajar IPA peserta didik materi pokok sifat-sifat cahaya dengan menerapkan model pembelajaran Guided Discovery kelas pada V di SDN 7 Selat Hulu Kuala Kapuas tahun pelajaran 2014/2015.

\section{KESIMPULAN}

Berdasarkan hasil penelitian yang telah dibahas maka dapat disimpulkan beberapa hal yaitu:

1. Aktivitas belajar peserta didik pada saat pembelajaran berlangsung menggunakan model pembelajaran Guided Discovery pada mata pelajaran IPA tentang materi sifat-sifat cahaya, lebih aktif dalam belajar.

2. Ada peningkatan hasil belajar IPA dengan menerapkan model pembelajaran Guided Discovery pada peserta didik kelas V SDN 7 Selat Hulu Kuala Kapuas.

\section{DAFTAR PUSTAKA}

Hamalik Oemar, 2007, Kurikulum dan Pembelajaran, Jakarta : Bumi Aksara.

Kemmis, stephen dan Robin Mc Taggart. 1998. The action research planner. Victoria: Deakin University

Sanjaya. 2011. Kurikulum dan Pembelajaran. Jakarta: Kencana Prenada Group.

Slameto, 2006. Belajar dan Faktorfaktor yang Mempengaruhinya. Jakarta: PT. Rineka Cipta.

Wisudawati, Asih Widi \& Sulistyowati, Eka. 2013. Metodologi Penelitian IPA- Cet. 1-Jakarta : BumiAksara. 